\title{
William Davies, This Is Not Normal: The Collapse of Liberal Britain
}

\author{
Verso, 2021, pp. vi + 249, ISBN: 978-1839760907
}

\author{
Patricia Thane $^{1}$
}

Published online: 30 September 2021

(๑) The Author(s), under exclusive licence to Springer Science+Business Media, LLC, part of Springer Nature 2021

This study of contemporary British politics opens rather optimistically in early 2016 when, Davies believed, "the Liberal centre was still - just - in command' before being destroyed" in the following four years, following the Brexit referendum. The book analyses when and how this came about.

The chapters draw on blogs or articles Davies published in the Guardian, New York Times, and London Review of Books at key times between the morning after the EU referendum in June 2016 and following the election of December 2019. He provides revealing insights into how things appeared at those times. The overarching theme is "the shift from a liberal polity based around norms, laws, expertise and institutions to a neoliberal one based around algorithmic surveillance and financial calculation" (p. 24) and how it developed.

After the shock of the referendum result, he tried to understand the strength of the Brexit vote in "left behind" areas like north-east England and South Wales, hit by the decline of coal mining and manufacturing since the 1980s. They gained substantial EU subsidies but were not grateful, he judged, for "elite handouts" that did not solve their problems. They wanted "to take back control", which to them meant regaining independence and self-respect, and return to a state that could deliver security to its citizens. They felt respected by Farage and Tory Brexiteers but ignored by a liberal elite they thought were more concerned to encourage multiculturalism and immigration.

This was just one feature of a wider revolt against liberal democracy. Davies traces it to the decline of industry and rise of finance in the 1980s, when the rich got ever richer, the poor poorer, inequalities that continued, narrowing

Patricia Thane

p.thane@bbk.ac.uk

1 Birkbeck College London, London, UK under New Labour but in ways that subsidised the victims without restoring their independence. State support for the banks after the 2008 crisis, followed by greater cuts to welfare and work opportunities under "austerity" from 2010, deepened feelings of abandonment and disillusion. Britain became more unequal than at any time since the 1930s and than most other OECD countries. From the 1980s, finance became increasingly powerful in politics, fuelling neoliberalism, the guiding ideology of the Thatcher governments, undermining the relatively cohesive liberal state that reached its peak from 1945 to the 1970s.

Davies recognises support for "Leave" also among older people, mainly men, in the south of England who had prospered since the 1980s and resisted liberal critiques of inequalities. Also, he notes the Leave/Remain division between those with and without higher education, another age divide. The "baby boomer" generation got free university education but in the 1960 s only $6 \%$ of $18-21$-year-olds attended university compared with $40 \%+$ since the 1980 s. Graduates tend to have broader and more international experience, often seeing themselves as "citizens of the world", disparaged by Theresa May as "citizens of nowhere" in her September 2016 Tory Party conference speech.

Disillusion with educated elites was fuelled from the 1980s by the contempt of Thatcher and her government for public service professionals, including civil servants and schoolteachers, who were represented as narrowly selfinterested. This encouraged mistrust of "experts" and the information they tried to disseminate which sceptics felt did not help them because the world is more complex than the presentation of official statistics always allows for. UK averages of expanding GDP do not convey the reality of the economy as many individuals experience it; immigration may be good for the economy as a whole, but may not benefit all localities. And governments manipulate statistics. Conservative governments from 2010 boasted that unemployment fell to the lowest levels since the early 
1970s, which was strictly true but masked a huge growth in underemployment and precarity in the expanding "gig economy". Hence, Leavers found it easy to reject Remainers' factual warnings about the outcomes of Brexit, and their criticism of Leaver "facts", including the claim on the side of a battle bus of the $£ 350$ m per year allegedly paid to the EU to be redirected to the National Health Service (NHS).

Anti-liberal/anti-elite sentiments were reinforced by "fake news" from digital platforms, increasingly targeted at vulnerable voters. And an increasingly strident right-wing press encouraged hostility to immigrants, the EU, and state welfare and its beneficiaries, and promoted politicians who shared these views. Hostility to immigrants was deepened by the "hostile environment" policy and stricter immigration controls developed by Theresa May as Home Secretary from 2010. Real news was damaging too. Davies describes how digital and mainstream media revealed previously hidden scandals, leaks, and government fraud, including the MPs' expenses scandal of 2009, revealed by the Daily Telegraph, the 2011 phone-hacking scandal which discredited the mainstream press and the police, and in 2012 the Jimmy Savile scandal undermined the BBC. Previously hidden sources were now accessible on-line and raised questions about what else was hidden, hardening mistrust of politicians and officials, encouraged by populists like Farage. Part of the problem, Davies argues, is the "explosion of information" from multiple sources which makes it even harder than usual to identify "truth". He acknowledges that scepticism is desirable in public life, but it has gone too far.

He concludes that the real inequalities in Britain are no longer determined by class, but by finance and education and do not correspond with the traditional "Labour"/ "Conservative" divide. The traditional middle class and aristocracy no longer dominate politics, replaced by the financial elite. Class still powerfully influences peoples' lives but it has become politically and culturally less important.

He moves on to discuss the June 2017 election. Writing in May 2017 he expected a Conservative landslide, despite Theresa May substituting repeated slogans-"Strong and stable leadership"- -for policies, standing before the Union Jack, seeking to personify the nation-state and claiming to support “ordinary working people", while Corbyn's Labour Party "regularly put out clear and reasonable policy proposals" (p. 82). Then, Corbyn did unexpectedly well, just 800,000 votes behind the Tories but 56 seats behind in a hung parliament. Davies judges that Corbyn gained by recognising and promising to counter the pain of austerity, especially attracting younger voters. It was perhaps not so surprising, since $48 \%$ of the UK electorate had voted "Remain" in the referendum from a turnout of less than $73 \%$, suggesting that Liberal sentiments had not disappeared, though they were no longer in control.
Soon after came the Grenfell Tower disaster which May handled badly, then the Windrush scandal (exposed by the liberal Guardian) for which she was ultimately responsible, intensifying criticism of her leadership from all sides. Davies describes how a more strident nationalism, hard neoliberalism, and demands for a "hard Brexit" grew within the Conservative party which May strove to avoid, rightly perceiving the danger especially to the economy, causing Boris Johnson and David Davies to resign from her Cabinet. They had no clearer policies than she, just rhetoric: the meaning of "hard Brexit" was quite unclear.

For Davies, politics in Britain and the USA after the election of Trump in 2016, became a media performance, especially appealing to politicians who, like Johnson and Trump, had media experience. As he puts it: "Politics and comedy are dissolving into one another in disturbing ways" (p. 151). Politicians had become increasingly obsessed with their media representation as it became more influential, most obviously in the case of Tony Blair. It became harder to avoid with the emergence of the 24-h news cycle as politicians faced persistent public comment. Theresa May was always uncomfortable if caught off-guard, the opposite of Johnson.

Davies observes how, between the elections of 2017 and 2019, Brexiteers demanded "sovereignty" for Britain, without defining the implications, while showing no interest in the prosaic, fact-based problems and need for long-term thinking which face governments, including when negotiating exit from the EU. They disparaged civil servants who took such details seriously. Amid the uncertainty, polls by 2019 showed consistent leads for Remain. Then, in May 2019, in the EU election, after Britain failed to meet the target of leaving the EU on the 29th of March, Farage's Brexit party won $30.5 \%$ of votes, the Conservatives $8.5 \%$. May resigned. The combined Remain parties, the Liberal Democrats, and Greens gained $31.4 \%$, the divided Labour Party $13.7 \%$.

Davies describes how the "notoriously reckless figure" of Boris Johnson was then elected to the premiership, not by the nation but by a Conservative party heavily infiltrated by supporters of Farage, mainly older white men enthusiastic about Johnson's apparent commitment to "no deal", despite his being "hounded by questions surrounding his honesty and indiscretion" (p. 172). In the leadership campaign Johnson, and his leading opponent Jeremy Hunt, toured the nation and TV studios "misreporting the economic, legal, political realities that will confront the next PM", Johnson making empty, sometimes unrealisable, promises including ending austerity. Davies believes the campaign further encouraged scepticism of anyone claiming to present objective facts or any utterance by a public figure. Johnson was elected in May 2019 and the onslaught on liberalism intensified, including on its adherents in his own party. In September 2019, 21 
anti-Brexit Tory MPs were purged from the party and others resigned. There were attacks on professionals previously respected as independent public servants, including judges, and media critics of Brexit and the government, including Channel 4 News and the Daily Mirror, were denied access to ministers and government press briefings.

Following his election, Davies thought it possible Johnson could win a workable majority in a national election, funded by wealthy funders of the Leave campaign, including "private equity barons and hedge fund managers" expecting to gain from No Deal, supported by voters hostile to multiculturalism, financiers making money in London terrified by Corbyn, uninterested in economic or social policy and only anxious to defend private wealth, and by the right-wing press which had built strong links with the Conservative party: some papers effectively became "campaign leaflets". With digital media, they attacked the "biased" liberal media, including the BBC, and "provided Johnson with his longsought opportunity to perform his pointless egotism on the highest stage in the land" (p. 184). When Johnson called an election for December 2019, Davies was not optimistic about either main party, pointing out that "If you survey the central tenets of Tory ideology from the past fifty years, it is hard to find a single one that is still intact" having disintegrated since the 1980s (p. 218). He describes how the party of business was undermining access to the half-billion EU market. "The party of 'family values' has fallen for a famous philanderer who doesn't know how many children he has" (p. 218). The "party of the establishment is provoking a constitutional crisis" by requesting suspension ("prorogation") of parliament to prevent MPs blocking a no-deal Brexit, angering the Queen, while "the party of law and order raged at the judiciary" for overturning it, and it "expelled some of its most distinguished MPs". He believed that Johnson and his Chief Adviser, Dominic Cummings, "will say or do anything to achieve their ends" (p. 219). A series of resentments had replaced Tory ideology—against immigrants, political correctness, Brussels, the vast riches being made in London. The entire 2019 Conservative election platform "hangs on the idea that parliament and Whitehall are betraying 'the people'...pursuing their own political agenda" (p. 224). "New Conservatism mocks the idea of fairness and independence". He saw Brexit as a consequence and accelerator of the decline of liberal democracy.

But the outcome of the election remained uncertain to a late stage. Polls showed both major parties in crisis, at 19\% behind both Liberal Democrats and Brexit, abandoned by Leave and Remain voters. On social media Farage loudly promoted "No Deal" and the need to fight against Westminster politicians who were betraying "the people" who voted for Brexit. However, polls suggested that this did not have majority support except among financially secure over60 s. Davies had "no doubt" that a "solid majority", 70\%, including conventional business lobbies well-served by the EU and most people under 50, who cared more about climate change than Brexit, supported parliamentary democracy, "fervently opposed no deal and were appalled by the demagogic posturing of Johnson and Farage". But there was little sign of the organization and leadership needed to bring them election victory. Corbyn's doubts about the EU alongside his pacifism made him unattractive.

Johnson won a substantial majority with $43.6 \%$ of votes, while Labour sank to $26 \%$, its worst result since 1935 , while the Brexit Party sank to 2\%. Amid Labour tensions and infighting, Corbyn was replaced as leader by the more moderate but less politically experienced lawyer, Sir Keir Starmer. The hopes of Brexiteers now focussed on Johnson. Davies judges that Johnson's success owed much to his sharing popular hostility to supreme court judges and MPs overturning proposals-self-interested elites acting against the interests of "the people".

Davies' third chapter reflects on Johnson's victory and premiership. In December 2019, "amid Conservative triumphalism and Labour feuding", he contemplated "how deeply abnormal the Conservative election campaign has been and how frighteningly unfamiliar the impending government could be" (p. 228). Johnson had revealed no policy agenda other than leaving the EU and winning former Brexit party voters, engaged in no serious democratic dialogue, "just performing by dressing up as a milkman or driving a forklift truck". He was "funded by hedge funds and wealthy entrepreneurs. But who knows what they get in return?" (p. 229), while "the chances of it offering anything transformative to former Labour voters is minimal" (p. 229). The government would not be accountable since Johnson and Cummings ignored the norms of liberal democracy. Davies fears it could lead to "a form of democracy that looks more like Hungary or even Russia than the checks-and-balances system of liberal 'ideals' ... but sufficiently funny or soothing to be tolerated" (p. 230). He argues that Johnson, assisted or guided by Dominic Cummings, his "attack dog", "crafted a new style of leadership", hostile to the liberal apparatus of government including parliament, the civil service and the law and the liberal media (p. 161). Cummings, writes Davies, condemns the "stagnant" public sector and thinks "MPs are a pompous waste of space; civil servants self-interested cowards whose main function is to thwart policy", which, he believes, "is almost an orthodoxy in pubs up and down the country" (pp. 213-214).

The book concludes with an "Afterword: In the wreckage of Liberalism" written in early 2020, after the unforeseeable onset of COVID. He describes how the pandemic challenged the posturing of the new government. Following the trashing of public sector administrators and technocrats, COVID "placed huge public demand on scientists and administrators, throwing statistics into the media spotlight" amid an 
urgent need to focus on verifiable facts and communicate them as precisely as possible, to save peoples' lives (p. 232). At daily press conferences, Johnson or his Cabinet colleagues were flanked by scientific and medical advisors, of the sort Johnson and his closest allies had long disparaged. After his hospitalization with coronavirus, Johnson and the Conservative press enthusiastically celebrated the public sector NHS. Meanwhile Britain had the worst death rate in Europe, especially among deprived, especially ethnic minority communities and in (largely privatized) care homes, due to Johnson's slowness to take preventive measures like locking down, while contracting out supply of essential equipment and services to incompetent profit-making companies, often with close personal ties to government members or to Cummings, which was costly and harmful because they undermined the efficiency of essential health care. Cummings displayed his typical lack of concern for established norms by travelling north with his family while suffering from coronavirus when this was forbidden in lockdown. It was revealed by his most-hated newspapers, the Mirror and the Guardian, and aroused much public criticism but he showed no repentance and Downing St stood by him.

Public trust in the government plummeted, amid protest movements including Black Lives Matter, about climate change, and the toppling of monuments to slavery, while continuing resistance to scientific fact surfaced in anti-vaccination demonstrations and fake news on social media. The pandemic intensified and made more public social crises that had been growing for some time-increasing poverty causing homelessness and ever more starving families needing food banks-though it also revealed an unexpected level of community mutual support and social cohesion not discussed by Davies. Patterns of work and consumption were changed and questioned-how permanently it is too soon to know. Yet Davies points out that the post-Brexit Conservative regime had not changed, still attacking universities, the civil service, and judiciary and the critical media, proposing to privatize Channel 4, tightening immigration rules and tabling a Bill severely limiting freedom of public protest.

He does not point out, presumably because it came too late for the book, that in November 2020 Johnson dismissed
Cummings, whose criticisms were causing too much tension with Tory MPs, civil servants, and Ministers and even Johnson's new wife. Six months later, Cummings took revenge in a 7-h interview with institutions he had previously attacked, two House of Commons committees. He attacked the government's poor handling of the pandemic, stating that "thousands" of people were better suited to running the country than Johnson, who had opposed all lockdowns and refused to take advice. His criticisms were repeated in an hour-long interview with the BBC, the "biased" broadcaster he had sought to strip of its public service status. He was clearly as self-serving as he had assumed all such public institutions to be.

Davies concludes by repeating his appeal that the liberal centre and left must organize together or the nationalist right will take over, as has happened in too many democracies around the world. It should build on evident public concerns including about child poverty, the (lack of) care for older people, and underfunding of the NHS. He points out that the pandemic has given unprecedented prominence and plausibility to long-standing liberal-socialist ideals like Universal Basic Income. "A coalition of legal and economic rebuilders is needed" (p. 242). But he does not suggest where leadership and organization might be found, and, after this persuasive analysis of 40 years of neoliberalism and the powerful groups and individuals supporting it, it is hard to be optimistic.

Publisher's Note Springer Nature remains neutral with regard to jurisdictional claims in published maps and institutional affiliations.

Patricia Thane , FBA, is Visiting Professor in History at Birkbeck College London. She is the author of several books including Divided Kingdom: A History of Britain, 1900 to the Present (2018) and Old Age in English History: Past Experiences, Present Issues (2000). 